\title{
ІСТОРИКО-ТЕОРЕТИЧНІ АСПЕКТИ ПОЛІКУЛЬТУРНОЇ КОМПЕТЕНТНОСТІ МАЙБУТНЬОГО ВЧИТЕЛЯ ІНОЗЕМНОЇ МОВИ
}

\author{
Віолетта Олішевич \\ кандидат педагогічних наук, \\ старший викладач кафедри іноземних мов Харківського національного \\ університету міського господарства імені О. М. Бекетова \\ м. Харків, Україна \\ ORCID ID 0000-0002-5809-3225 \\ olishevich.v@gmail.com
}

\begin{abstract}
Анотація. У статті досліджується поняття полікультурної компетентності майбутнього вчителя іноземної мови. Актуальність проблеми підсилюється активізацією міжкультурних інтеграційних процесів, змінами в галузі засобів комунікації, що призвели до кризи характерних для попередньої епохи монокультурних моделей розуміння суспільних процесів. Автором здійснено уточнення сутності поняття полікультурної компетентності майбутнього вчителя іноземної мови та визначено історико-теоретичні аспекти його функціонування. Розглянуто близькі за змістом поняття «полікультурність», «мультикультурність», «міжкультурний», «крос-культурний», «інтеркультуралізм» та ін. Наголошено на необхідності вивчення культури народу, мова якого вивчається, а також рідної культури за принципом діалогу культур, що є умовою формування полікультурної компетентності. Надано авторське тлумачення поняття «полікультурна компетентність майбутнього вчителя іноземних мов» як інтегративної якості особистості майбутнього фахівця, що включає систему полікультурних знань, умінь, навичок, інтересів, потреб, мотивів, цінностей, полікультурних якостей, досвіду, соціальних норм і правил поведінки, які формуються в процесі професійної мовної підготовки через ознайомлення з культурою інших народів за принципом діалогу культур та в умовах неперервної комунікативної практики.
\end{abstract}

Ключюві слова: полікультурна компетентність; мультикультурність; інтеркультуралізм; мовна підготовка; майбутні вчителі іноземної мови.

Постановка проблеми в загальному вигляді. Процеси глобалізації, які є цивілізаційними домінантами сучасного розвитку людства та передбачають посилення міжкультурних інтеграційних процесів, спричинили актуальність проблеми формування полікультурної компетентності майбутніх учителів іноземних мов. Зміни в галузі засобів комунікації призвели до кризи характерних для попередньої епохи монокультурних моделей розуміння суспільних процесів, зробивши полікультурність ціннісним критерієм суспільного розвитку. Україна долучається до процесів інтеграції у світове співтовариство, що викликає помітне збільшення інтересу до вивчення іноземних мов i, як результат, змінюються вимоги до підготовки фахівців із іноземних мов. Вони мають не лише досконало володіти мовними засобами іноземної мови, а вибудовувати власні стратегії міжкультурної взаємодії з представниками іншомовних культур.

(с ДВНЗ «Донбаський державний педагогічний університет» 


\section{В. ОЛІШЕВИЧ}

Історико-теоретичні аспекти полікультурної компетентності майбутнього вчителя іноземної мови

Світове суспільство розбудується в інтеграційному процесі взаємодії, консолідації культур різних етносів, у якому особистість перебуває на рубежі культур. Крім того, на сучасному етапі історії людство знову переживає світоглядну кризу, в умовах якої полікультурність набуває надзвичайної цінності. Сутність цієї кризи полягає в посиленні дезінтеграційних тенденцій у геополітичній сфері, загострення міжкультурних суперечностей (релігійного, етнокультурного, гендерного характеру), підвищенні ризиків і нестабільності соціального буття (тероризм, громадянські війни, революції).

Аналіз останніх досліджень і публікацій. Наукове осмислення сутності полікультурності та впровадження ефективних механізмів формування полікультурної компетентності у закладах вищої освіти $є$ дійсними викликами для української педагогічної науки. Наукові дослідження вітчизняних та зарубіжних учених, присвячені створенню полікультурного освітнього простору (С. Дрожжина (2008), М. Моцар (2018), J. Banks (2004), G. Gay (2018) та ін.); формуванню полікультурної компетентності майбутнього вчителя (В. Дьоміна (2017), О. Кондратьєва (2017) та ін.); полікультурному вихованню учнів у системі закладів загальної середньої освіти (П. Кендзьор (2017), Л. Перетяга (2008) та ін.), доводять, що «полікультурний» є своєрідною новелою в семантичному просторі, розподіленому термінами «мультикультурний», «міжкультурний», «крос-культурний», «інтеркультурний» і «транскультурний». «Полікультурний» виглядає як прямий синонім до «мультикультурного».

Представники американської (J. Banks (2004), C. Grant \& Ch. Sleeter (2007), G. Gay (2018)) та канадської (J. Berry (2008), M. Canale \& M. Swain (1981) та ін.) наукових шкіл вивчали проблему запровадження білінгвальної освіти, що була покликана встановити гармонійні відносити між представниками різних етнічних груп. Сучасні зарубіжні науковці (М. Byram (1997), М. Heyward (2002), D. Deardorff (2011), L. Perry \& L. Southwell (2011)), надають перевагу поняттям «інтеркультурний» та «крос-культурний». Вітчизняні вчені О. Бескорса, Л. Гаврілова, О. Ішутіна (2021) вивчають міжкультурну комунікацію в освіті й аналізують цифрові форми їі реалізації.

Формулювання цілей статті (постановка завдання). Спробуємо в межах статті уточнити сутність поняття полікультурної компетентності майбутнього вчителя іноземної мови та визначити історико-теоретичні аспекти його функціонування, поєднуючи історичну ревізію розвитку означеної проблеми в науці з логічною аналітикою ключового поняття.

Методи дослідження. Дослідження базується на низці теоретичних методів, серед яких аналіз, синтез, узагальнення та систематизація інформаційних даних науково-методичної літератури задля занурення в

Професіоналізм педагога: теоретичні й методичні аспекти. - Вип. 16. - Слов’янськ, 2021. 
історико-теоретичні аспекти полікультурної компетентності майбутнього вчителя іноземної мови.

Важливим методологічним підгрунтям вивчення окресленої проблеми став компетентнісний підхід, як такий, що поєднує в собі вимоги щодо професійної підготовки фахівців і потреби ринку праці, втілює ті глобальні тенденції, які відбуваються в світовому просторі, і досягти результатів, які виходять далеко за межі самої системи освіти (Моцар, 2018). Окрім того, компетентнісний підхід акцентує увагу на результаті освітньої діяльності, якою вважається не кількість засвоєної інформація, а спроможність особистості діяти в певних ситуаціях.

Для усвідомлення сутності полікультурної компетентності актуальним виявився й культурологічний підхід, що сприяє усвідомленню загальних зав'язків освіти та культури. В контексті підготовки майбутніх учителів зміст цього методологічного підходу передбачає наявність знань та розуміння рідної, світової та іншомовної культури, а також норм міжкультурного спілкування та оволодіння культурою світу - культурою безконфліктного спілкування (Олішевич, 2020).

Результати дослідження. Поняття «полікультурність» увійшло в історію педагогічної науки в другій половині XX століття та найбільшого розповсюдження цей термін набув у країнах, де відбувалися масові імміграційні процеси, зокрема США, Канада, Австралія. Так, у 60-80 роки XX століття в Америці широковживаним був термін «мультикультуралізм», що вважався семантично наближеним до поняття полікультурності, зміст якого характеризував політику і ідеологію держави щодо етнічного та культурного розмаїття суспільства, у якому різні культури можуть співіснувати не виявляючи ознак домінування однієї культури над іншою. У ході розвитку суспільства поняття «мультикультуралізму» зазнавало деяких змін у бік його суб'єктування. Це означає, що мультикультуралізм сприймався як позитивна ознака поліетнічного суспільства 3 толерантним ставленням до його представників, які мають певні соціальні, расові та культурні відмінності (Олішевич, 2020, с. 61).

Американський вчений J. Banks уперше наголосив на необхідності створення мультикультурного освітнього середовища, усі аспекти якого, зокрема зміст навчальних дисциплін, методи оцінювання, стиль та форми взаємодії учасників освітнього процесу, мають бути трансформовані та адаптовані відповідно до тих вимог, які висуває суспільство перед системою освіти (Banks, 2004). M. Canale \& M. Swain (1981) довели, що поняття мультикультуралізму тісно пов'язане з формуванням комунікативної компетентності, що є головною метою вивчення будь-якої мови, і знаходиться під впливом соціокультурних факторів, а саме мотивації, ставлення, толерантності, емпатії тощо.

() ДВНЗ «Донбаський державний педагогічний університет» 


\section{В. ОЛІШЕВИЧ}

Історико-теоретичні аспекти полікультурної компетентності майбутнього вчителя іноземної мови

У 80-ті роки XX століття виникло поняття «інтеркультуралізму», сутність якого полягала у встановленні діалогу різних культур у суспільстві. Ch. Taylor провів дослідження щодо окреслення відмінностей між мультикультуралізмом та інтеркультуралізмом, у результаті якого було встановлено, що мультикультуралізм здебільшого фокусується на мирному співіснуванні різних культур, а інтеркультуралізм наголошує на необхідності співпраці представників різних культур, маючи спільні цілі і простір, у межах якого вони взаємодіють (наприклад, освітнє середовище) (Taylor, 1994). Вивчення еволюції поняття полікультурності дає змогу глибше усвідомити його сутність, зокрема інтеркультурна парадигма акцентує увагу на діалозі культур.

Проте, у 80-ті роки ХХ століття, діалог культур був суто філософським концептом i, враховуючи той факт, що рівень культурної агресії в ті часи процвітав, можна стверджувати, що він представляв собою лише теоретичні ідеї, які не мали практичного втілення в реальних умовах соціальної взаємодії. Тому діалог культур мав перетворитися на ціль спілкування між людьми в полікультурних спільнотах i саме освіта є культуро-утворювальним середовищем, у якому реалізується полікультурна комунікація.

У XX столітті увага науковців була привернута до діалогічних концепцій взаємодії та теорії комунікації, які є головними концептами полікультурного простору. У відомих працях Е. Гуссерля (теорія інтерсуб'єктивності), М. Бубера (учення про подію «Я й Ти»), М. Бахтіна й В. Біблера (діалогічні концепції), К. Ясперса (екзистенціальна комунікація) надається тлумачення міжкультурної комунікації в полікультурному просторі як засобу реалізації взаємозв'язку між культурами. У сучасних термінологічних словниках поняття «комунікація» має три головні дефініції та інтерпретується як засіб зв'язку будь-яких об'єктів матеріального й духовного світу; спілкування - передача інформації від людини до людині; передача й обмін інформацією в суспільстві.

Аналіз сучасних наукових праць представників вітчизняної та зарубіжної наукових спільнот дозволив виділити розбіжності щодо вживання наукових понять, які безпосередньо стосуються сутності поняття «полікультурна компетентність». Так, у зарубіжних розвідках (M. Byram (1997), M. Heyward (2002), D. Deardorff (2011), L. Perry (2011) дефініція «інтеркультурний» переважно використовується в комбінаціях «інтеркультурна компетентність» або «інтеркультурна комунікація». «Інтеркультурний» у змісті цих понять означає інтеграцію різних культур, їх взаємодію та взаємопроникнення. Західні вчені також наголошують, що підгрунтям для здійснення такої взаємодії $є$ знання мови. Щодо поняття «крос-культурний» за значенням воно є наближеним до поняття «інтеркультурний» і також розглядається науковцями в контексті

Професіоналізм педагога: теоретичні й методичні аспекти. - Вип. 16. - Слов’янськ, 2021. 


\section{В. ОЛІШЕВИЧ}

Історико-теоретичні аспекти полікультурної компетентності майбутнього вчителя іноземної мови

вивчення іноземних мов, проте поширенішою $\epsilon$ словосполучення «кроскультурна освіта». Головна відмінність крос-культурної освіти від інтеркультурної, як вказують J.-Y. Jo \& J. Kwon (2019), полягає в інтегруванні двох і більше культур і вона може стосуватися не лише іншомовного контексту, а має включати культурологічний та соціокультурний компонент як у зміст усіх навчальних дисциплін, так і в методи та форми навчальної взаємодії.

В українських наукових джерелах більш вживаними $є$ поняття «міжкультурний» та «полікультурний», які використовуються у контексті освіти загалом та у світлі формування відповідних компетентностей зокрема. Так, аналіз поняття «міжкультурна компетентність» висвітлено в працях українських учених А. Костюченко (2015), М. Моцар (2018), О. Резунова (2021), які стверджують, що воно базується на механізмі мовленнєвої взаємодії 3 представниками іншої культури. Порівнюючи дослідження вітчизняних та зарубіжних науковців, ми можемо зробити висновок, що «інтеркультурний» та «міжкультурний» $€$ синонімічними поняттям. Натомість під поняттям «полікультурний», яке переважно використовується в сполученні слів «полікультурна освіта» та «полікультурне виховання» розуміють взаємодію багатьох соціумів, що є носіями різних систем цінностей та уявлень про життя. Тому, головний акцент у такій освіті вчені П. Кендзьор (2017) та І. Бахов (2017) роблять на розширенні полікультурного світогляду, що вимагає від суб’єктів освітнього процесу формування такої якості, як відкритість до сприйняття культур інших народів.

На сучасному етапі розвитку суспільства політика полікультуралізму широко впроваджується в європейських країнах, які є по суті монокультурними, проте, у яких виявляються певні культурні розбіжності, що мають історичне підгрунтя. Передусім до таких країн належать Іспанія, Польща та країни пострадянського простору. У документах ООН, ЮНЕСКО та Ради Європи зазначено, що головним завданням системи освіти є підготовка сучасної молоді до життя в полікультурному суспільстві та оснащення молодих європейців компетентностями задля сприйняття відмінностей, виховання поваги до інших та розвиток здатності жити з людьми інших культур та мов.

Проблема полікультурності для українського суспільства $\epsilon$ вкрай актуальною, тому що, по-перше, в Україні мешкають представники різних національностей, які мають різний культурний бекграунд, по-друге, конфлікт, який переживає зараз країна, напряму корелює зі сплеском пострадянської ностальгії й відсутністю порозуміння зі світовою спільнотою, що засвідчують брак полікультурного виховання й диктують потребу в реалізації 


\section{В. ОЛІШЕВИЧ}

Історико-теоретичні аспекти полікультурної компетентності майбутнього вчителя іноземної мови

компетентнісного підходу в напрямі формування вмінь та навичок здійснювати полікультурну взаємодію на всіх рівнях освітнього процесу.

Процеси глобалізації та інтеграції українського суспільства до полікультурної світової спільноти посилюють інтерес до вивчення іноземних мов. Мовна освіта сприяє формуванню культурної ідентичності особистості, а також підвищує рівень іï соціальної мобільності у полікультурному суспільстві. Мовна політика є одним із ключових орієнтирів у програмах Європейського союзу. У 2009 році на засіданні Ради Європи з освіти, молоді та культури було прийнято Рамкову стратегічну програму $\mathrm{CC}$ щодо співробітництва у сфері освіти, реалізація якої триває до 2020 року. У цьому стратегічному документі наголошено, що пріоритетною стратегією $є$ вивчення двох іноземних мов, починаючи з раннього віку в закладах загальної середньої освіти і далі має стати частиною діяльності закладів технічної та вищої освіти. Також на засіданні Ради Європи в 2008 році була затверджена Біла книга з міжкультурного діалогу «Жити разом в рівності та гідності», у якій обгрунтовано роль вивчення іноземних мов у формуванні культурної та соціальної ідентичності особистості, збагаченні іiі та розвитку іiі полікультурної компетентності (White Paper, 2008).

Зважаючи на те, що Україною підписано Угоду про Асоціацію 3 Європейським Союзом, подолання мовного бар'єру, який сьогодні залишається наявним між нашою країною та європейськими країнами, $є$ пріоритетним державним завданням на нормативно-правовому рівні. У Законі України «Про освіту» (2017) зазначено, що метою повної загальної освіти в Україна $\epsilon$ виховання та соціалізація особистості, здатної жити в суспільстві, що досягається через формування ключових компетентностей, однією 3 яких є здатність спілкуватися рідною та іноземними мовами.

Ми вважаємо формування полікультурної компетентності важливим у процесі професійної підготовки майбутніх учителів іноземних мов, адже першочерговим завданням вчителя є координування ціннісним розвитком учнів через зміст навчального предмету. Як відомо, вивчення іноземних мов зосереджено не лише на засвоєнні мовного матеріалу та формуванні вмінь у різних видах мовленнєвої діяльності, а також глибоке засвоєння культурних особливостей країни, мова якої вивчається. Ми також розділяємо думку О. Кондратьєвої (2017), що формування полікультурної компетентності майбутніх учителів сприяє розширенню загального кругозору студентів, формуванню поліфонічного сприйняття світу, виховує толерантне ставлення до представників інших культур як норму поведінки в суспільстві. На наше глибоке переконання, формування полікультурної компетентності майбутніх учителів іноземних мов має бути спеціально організованим процесом, результатом якого

Професіоналізм педагога: теоретичні й методичні аспекти. - Вип. 16. - Слов'янськ, 2021. 


\section{В. ОЛІШЕВИЧ}

Історико-теоретичні аспекти полікультурної компетентності майбутнього вчителя іноземної мови

є можливість взаємодіяти в різних сферах суспільного життя з представниками різних народів та культур (Кондратьєва, 2017).

Відзначимо, що зміст поняття «полікультурність» залежить від первісного визначення поняття «культура», що, будучи родовим абстрактним поняттям, $\epsilon$ надзвичайно вразливим для перекручень змісту. Теоретичний аналіз науковопедагогічної літератури дозволяє констатувати наявність різних визначень поняття «полікультурна компетентність», для уточнення сутності якого нами були проаналізовані ідеї вітчизняних та зарубіжних учених. Характерним для українських науковців є визначення полікультурної компетентності як складного індивідуального утворення, що грунтується на певних теоретичних знаннях та об'єктивних уявленнях про етнокультурну своєрідність суспільства та реалізується через уміння, навички й моделі поведінки (Кондратьєва, 2017; Кендзьор, 2017; Перетяга, 2008 та ін.). На нашу думку, таке визначення також не розкриває поняття полікультурної компетентності, а зіставляє його $з$ поняттями етнокультурної освіченості та міжкультурної взаємодії, зміст яких залишається умовно загальновідомим. Проте, цінність цього визначення полягає в тому, що особистість, у якої сформована ця компетентність, є носієм досвіду під час міжособистісної взаємодії із представниками різних культур.

Попри значну увагу науковців до вивчення змісту полікультурної компетентності як необхідної складової оновлення змісту української освіти відкритим залишається питання щодо єдиного визначення поняття полікультурної компетентності саме в контексті педагогічної освіти, а також формування полікультурної компетентності майбутніх учителів іноземних мов як однієї з провідних компетентностей у структурі їхньої професійної діяльності.

Л. Чередниченко в своєму дослідженні резюмує, що полікультурна компетентність майбутнього вчителя - «це інтегроване професійно-особистісне утворення, результативний компонент професійної підготовки, що обумовлює готовність майбутнього вчителя до ефективного здійснення педагогічної діяльності у багатонаціональному середовищі» (Чередниченко, 2013, с. 334). Також у контексті підготовки вчителя іноземних мов розглядає полікультурну компетентність I. Бахов (2017) як сукупність різних форм взаємодії і спілкування між індивідами та групами, які є представниками різних культур. Важливість формування полікультурної компетентності майбутніх учителів іноземних мов зумовлена загальною роллю вчителя як координатора ціннісного розвитку дитини та транслятора предметного змісту. Головною метою навчання іноземної мови є не лише засвоєння мовного матеріалу та формування комунікативної компетентності, а й формування системи знань щодо культурних особливостей країни, мова якої вивчається.

() ДВНЗ «Донбаський державний педагогічний університет» 


\section{В. ОЛІШЕВИЧ}

Історико-теоретичні аспекти полікультурної компетентності майбутнього вчителя іноземної мови

Учені наголошують на необхідності вивчення культури народу, мова якого вивчається, а також рідної культури за принципом діалогу культур, що на їхню думку, є умовою формування не тільки полікультурної компетентності, а й становлення уявлення, що діалог культур виступає як єдина філософія існування в сучасних полікультурних спільнотах, яка характеризується етнічною, релігійною та соціальною толерантністю до представників інших культур.

Широковідомим у сучасній педагогічній літературі є також визначення, запропоноване українськими вченими С. Сисоєвою та I. Соколовою, за яким полікультурна компетентність майбутнього вчителя - «це інтегративна якість особистості майбутнього фахівця, що формується в процесі навчання та включає систему полікультурних знань, умінь, навичок, інтересів, потреб, мотивів, цінностей, полікультурних якостей, досвіду соціальних норм і правил поведінки, необхідних для повсякденного життя й діяльності в сучасному полікультурному суспільстві» (Сисоєва \& Соколова, 2016, с. 65-66). Однак, таке визначення $\epsilon$ загальним і в ньому не враховано специфіку підготовки майбутніх учителів саме іноземних мов.

У контексті підготовки майбутніх учителів іноземних мов близьким до предмету нашого дослідження є вивчення проблеми взаємозв’язку професійної та полікультурної компетентності майбутніх фахівців, висвітлене в наукових працях Н. Величко. Учена має дві точки зору на зазначену проблему: по-перше, вона вважає, що професійна й полікультурна компетентності є однопорядковими (рівнозначними) та є компонентами загальножиттєвої компетентності; по-друге, полікультурна компетентність $є$ складовою професійної компетентності педагога (Величко, 2010).

У своєму дослідженні ми розділяємо другу точку зору Н. Величко і маємо підстави стверджувати, що полікультурна компетентність входить до складу професійної компетентності майбутнього вчителя, адже полікультурна компетентність є необхідною умовою успішної професійної діяльності та педагогічної майстерності педагога. Ефективність професійної діяльності вчителя іноземних мов безпосередньо залежить від уміння добирати, структурувати зміст навчання іноземної мови, здійснюючи культурологічний та етнічний вплив у процесі освітньої діяльності, застосовуючи технології, що враховують індивідуально-особистісні інтереси учнів, світові тенденції та національні пріоритети мовної освіти (Величко, 2010).

На основі проведеного теоретичного аналізу термінологічної сутності поняття «полікультурна компетентність» вважаємо, що «полікультурна компетентність майбутнього вчителя іноземних мов»-ц̧е інтегративна якість особистості майбутнього фахівия, щзо включає систему полікультурних знань,

Професіоналізм педагога: теоретичні й методичні аспекти. - Вип. 16. - Слов’янськ, 2021. 


\section{В. ОЛІШЕВИЧ}

Історико-теоретичні аспекти полікультурної компетентності майбутнього вчителя іноземної мови

умінь, навичок, інтересів, потреб, мотивів, цінностей, полікультурних якостей, досвіду, соціальних норм $i$ правил поведінки, які формуються в прочесі професійної мовної підготовки через ознайомлення з культурою інших народів за принцииом діалогу культур та в умовах неперервної комунікативної практики.

\section{Висновки 3 дослідження і перспективи подальших розвідок у цьому} напрямі. Проведений аналіз вітчизняних i зарубіжних джерел дозволяють стверджувати, що процес формування полікультурної компетентності майбутніх учителів іноземних мов $є$ складним, динамічним і безперервним та вимагає урахування сучасних вимог полікультурного соціуму. 3'ясовано, що в основу докорінних змін у системі вищої педагогічної освіти покладено методологічні засади, які визначають роль учителя як суб'єкта полікультурної взаємодії. Предметом наявних наукових досліджень вітчизняної педагогічної науки $\epsilon$ полікультурне виховання учнів, створення полікультурного середовища в закладах загальної середньої освіти, формування полікультурної компетентності спеціалістів різних галузей (перекладачів, медиків) або компаративні вивчення тенденцій розвитку полікультурної освіти різних країнах світу. Практично поза увагою науковців залишається проблема формування полікультурної компетентності майбутніх учителів іноземних мов, актуальність якої доводить зростання потреб у підготовці висококваліфікованих фахівців із достатнім рівнем сформованості іншомовної комунікативної компетентності, які виконують роль медіаторів культур у процесі міжкультурної взаємодії.

На основі аналізу наукової літератури надано авторське тлумачення поняття «полікультурна компетентність майбутніх учителів іноземних мов», що дозволяє в перспективі дослідження переходити до структурування й опису компонентного складу поняття..

\section{СПИСОК ВИКОРИСТАНИХ ДЖЕРЕЛ}

1. Banks, J. A. (2004). Hand of Research on Multicultural Education / edited by J. A. Banks, C. A. M. Banks. San Francisco : Jossey-Bass.

2. Berry, J. W. (2008). Globalisation and acculturation. International Journal of Intercultural Relations, 32, 328-336.

3. Byram, M. (1997). Teaching and Assessing Intercultural Competence. Clevedon: Multilingual Matters Ltd.

4. Deardorff, D. (2011). Assessing intercultural competence. New Directions for Institutional Research, 149, 65-79. DOI: 10.1002/ir.381.

5. Gay, G. (2018). Culturally Responsive Teaching: Theory, Research, and Practice. 3d ed. New York : Teachers College Press.

6. Grant, C. \& Sleeter, C. (2007). Doing multicultural education for achievement and equity. New York : Routledge.

7. Heyward, M. (2002). From International to Intercultural : Redefining the International School for a Globalized World. Journal of Research in International Education, 1, 9-32. DOI: $10.1177 / 147524090211002$. 


\section{В. ОЛІШЕВИЧ}

Історико-теоретичні аспекти полікультурної компетентності майбутнього вчителя іноземної мови

8. Jo, J.-Y. \& Kwon, J. (2019). Conceptions and Approaches to Education Across Cultures. Cross-Cultural Psychology / edited by K. D. Keith. 271-286 DOI: 10.1002/9781119519348.ch12.

9. Perry, L. \& Southwell, L. (2011). Developing Intercultural Understanding and Skills : Models and Approaches. Intercultural Education, 22, 453-466. DOI: 10.1080/14675986.2011.644948

10. Canale, M. \& Swain, M. (1981). Theoretica1 Bases of Communicative Approaches to Second Language Teaching and Testings. Applied Linguistics, 1, 1-47.

11. Taylor, E. W. (1994). Intercultural Competency : A Transformative Learning Process. Adult Education Quarterly, 44(3), 154-174.

12. White Paper on intercultural dialogue : Living together as equals in dignity. (2008). Strasbourg : Committee of Ministers, Council of Europe. URL: www.coe.int/t/dg4/intercultural/ source/white\%20paper_final_revised_en.pdf.

13. Бахов, І. С. (2017). Тенденції розвитку полікультурної освіти у професійній підготовці фахівців КАНАДИ і США (друга половина XX - початок XXI ст.). (Дис. д-ра пед. наук). Київ : Національний педагогічний університет ім. М. П. Драгоманова.

14. Бескорса, О., Гаврілова, Л. \& Ішутіна, О. (2021). Цифрові форми міжкультурної комунікації в освіті : досвід реалізації проєкту Еразмус+ Жан Моне Модуль. Фізикоматематична освіта, 29 (3), 44-50. DOI: 10.31110/2413-1571-2021-029-3-007.

15. Величко, Н. М. (2010). Полікультурна компетентність як складова професійної компетентності педагога. Вісник Житомирського державного університету, 54, 162-165.

16. Дрожжина, С. (2008). Полікультурна освіта : теоретичні засади реформування. Педагогічний дискурс. Хмельницький : ХГПА, 28-36.

17. Дьоміна, В. (2017). Концептуальні основи виховання білінгвальної культури у майбутніх учителів іноземних мов. Теорія та методика навчання та виховання, 43, 90-101. URL: http://journals.hnpu.edu.ua/index.php/methodics/article/view/836

18. Кендзьор, П. (2017). Полікультурне виховання учнів у системі діяльності загальноосвітнього навчального закладу (теорія і методика). (Дис. д-ра пед. наук). Київ : Академія педагогічних наук України. Інститут проблем виховання.

19. Кондратьєва, О. М. (2017). Формування полікультурної компетентності майбутніх учителів початкової школи (на засадах лінгвокраїнознавчого підходу) (Дис. канд. пед. наук). Київ : Національний педагогічний університет ім. М. П. Драгоманова.

20. Костюченко, А. (2015). Аналіз поняття «міжкультурна компетентність учителя». Педагогічні науки, 64, 29-33. URL: http://dspace.pnpu.edu.ua/bitstream/123456789/5578/1/Kostyuchenko.pdf.

21. Моцар, М. М. (2018). Формування полікультурної компетентності майбутніх перекладачів з використанням технологій дистанційного навчання (Дис. канд. пед. наук). Київ : Національний педагогічний університет ім. М. П. Драгоманова.

22. Олішевич, В. М. (2020). Формування полікультурної компетентності майбутніх учителів іноземних мов у процесі професійної підготовки (Дис. канд. пед. наук). Слов'янськ: ДВНЗ «Донбаський державний педагогічний університет».

23. Перетяга, Л. Є. (2008). Дидактичні умови формування полікультурної компетентності молодших школярів (Дис. канд. пед. наук). Харків : Харківський національний педагогічний університет імені Г.С. Сковороди.

24. Про освіту : Закон України від 05.09.2017 p. № 2145-VIII. URL: https://zakon.rada.gov.ua/laws/show/2145-19

25. Резунова, О. (2021). Міжкультурна компетентність як необхідна складова професійної компетентності сучасного фахівця. Науковий огляд, 1(73). URL: http://oaji.net/articles/2021/797-1614450760.pdf.

26. Сисоєва, С. \& Соколова, I. В. (2016). Теорія і практика вищої освіти : навчальний посібник. Київ-Маріуполь : МДУ.

Професіоналізм педагога: теоретичні й методичні аспекти. - Вип. 16. - Слов'янськ, 2021. 
Історико-теоретичні аспекти полікультурної компетентності майбутнього вчителя іноземної мови

27. Чередниченко, Л. А. (2013). Етапи формування полікультурної компетентності майбутнього вчителя іноземних мов у процесі професійної підготовки. Проблеми сучасної педагогічної освіти. Педагогіка і психологія, 39 (4), 333-337.

\title{
HISTORICAL AND THEORETICAL ASPECTS OF POLYCULTURAL COMPETENCE OF A FUTURE FOREIGN LANGUAGE TEACHER
}

\author{
Violetta Olishevich \\ Candidate of Pedagogical Sciences, \\ Senior Lecturer at the Department of Foreign Languages of the Kharkiv National \\ University of Municipal Economy named after O.M. Beketov \\ ORCID ID 0000-0002-5809-3225 \\ olishevich.v@gmail.com
}

\begin{abstract}
The article explores the concept of multicultural competence of future foreign language teachers. The urgency of the problem is exacerbated by the intensification of intercultural integration processes, changes in the field of communication, which led to a crisis characteristic of the previous era of monocultural models of understanding social processes. The author clarifies the essence of the concept of multicultural competence of a future foreign language teacher and identifies the historical and theoretical aspects of its functioning. The concepts of "multiculturalism", "multicultural", "intercultural", "cross-cultural", "interculturalism" and others are considered. Emphasis is placed on the need to study the culture of the people whose language is studied, as well as native culture on the principle of culture dialogue, which is a condition for the formation of multicultural competence.

It is found that the fundamental changes in the system of higher pedagogical education are based on methodological principles that determine the role of the teacher as a subject of multicultural interaction. The subject of existing research of Ukrainian pedagogical science is multicultural education of students, creating a multicultural environment in general secondary education, the development of multicultural competence of specialists in various fields (translators, physicians) or comparative studies of multicultural education in different countries.

The issue of formation of multicultural competence of future foreign language teachers is practically ignored by scientists. The urgency of this issue proves the growing need for training highly qualified specialists with a sufficient level of foreign language communicative competence, who act as cultural mediators in intercultural interaction. The author's interpretation of the concept of "multicultural competence of future foreign language teachers" as an integrative quality of the future specialist, which includes a system of multicultural knowledge, skills, interests, needs, motives, values, multicultural qualities, experience, social norms and rules of conduct in the process of professional language training through acquaintance with the culture of other peoples on the principle of dialogue of cultures and in the conditions of continuous communicative practice.

Key words: multicultural competence; multiculturalism; interculturalism; language training; future foreign language teachers.
\end{abstract}

\section{REFERENCES}

1. Banks, J. A. (2004). Hand of Research on Multicultural Education / edited by J. A. Banks, C. A. M. Banks. San Francisco : Jossey-Bass. [in English].

2. Berry, J. W. (2008). Globalisation and acculturation. International Journal of Intercultural Relations, 32, 328-336. [in English]. 


\section{В. ОЛІШЕВИЧ}

Історико-теоретичні аспекти полікультурної компетентності майбутнього вчителя іноземної мови

3. Byram, M. (1997). Teaching and Assessing Intercultural Competence. Clevedon : Multilingual Matters Ltd. [in English].

4. Deardorff, D. (2011). Assessing intercultural competence. New Directions for Institutional Research, 149, 65-79. DOI: 10.1002/ir.381. [in English].

5. Gay, G. (2018). Culturally Responsive Teaching: Theory, Research, and Practice. 3d ed. New York : Teachers College Press. [in English].

6. Grant, C. \& Sleeter, C. (2007). Doing multicultural education for achievement and equity. New York : Routledge. [in English].

7. Heyward, M. (2002). From International to Intercultural : Redefining the International School for a Globalized World. Journal of Research in International Education, 1, 9-32. DOI: 10.1177/147524090211002. [in English].

8. Jo, J.-Y. \& Kwon, J. (2019). Conceptions and Approaches to Education Across Cultures. Cross-Cultural Psychology / edited by K. D. Keith. 271-286 DOI: 10.1002/9781119519348.ch12. [in English].

9. Perry, L. \& Southwell, L. (2011). Developing Intercultural Understanding and Skills : Models and Approaches. Intercultural Education, 22, 453-466. DOI: 10.1080/14675986.2011.644948 [in English].

10. Canale, M. \& Swain, M. (1981). Theoretica1 Bases of Communicative Approaches to Second Language Teaching and Testings. Applied Linguistics, 1, 1-47. [in English].

11. Taylor, E. W. (1994). Intercultural Competency : A Transformative Learning Process. Adult Education Quarterly, 44(3), 154-174. [in English].

12. White Paper on intercultural dialogue : Living together as equals in dignity. (2008). Strasbourg : Committee of Ministers, Council of Europe. Retrieved from www.coe.int/t/dg4/intercultural/source/white\%20paper_final_revised_en.pdf. [in English].

13. Bakhov, I. S. (2017). Tendentsii rozvytku polikulturnoi osvity u profesiinii pidhotovtsi fakhivtsiv KANADY i SShA (druha polovyna XX - pochatok XXI st.) [Trends in the development of multicultural education in the training of specialists in CANADA and the USA (second half of the XX - beginning of the XXI century)]. (Doctoral dissertation). Kyiv : Natsionalnyi pedahohichnyi universytet im. M. P. Drahomanova. [in Ukrainian].

14. Beskorsa, O., Havrilova, L. \& Ishutina, O. (2021). Tsyfrovi formy mizhkulturnoi komunikatsii v osviti : dosvid realizatsii proiektu Erazmus+ Zhan Mone Modul [Digital forms of intercultural communication in education: the experience of the Erasmus + Jean Monnet Module]. Fizyko-matematychna osvita, 29 (3), 44-50. DOI: 10.31110/2413-1571-2021-029-3-007. [in Ukrainian].

15. Velychko, N. M. (2010). Polikulturna kompetentnist yak skladova profesiinoi kompetentnosti pedahoha [Multicultural competence as a component of professional competence of a teacher]. Visnyk Zhytomyrskoho derzhavnoho universytetu, 54, 162-165. [in Ukrainian].

16. Drozhzhyna, S. (2008). Polikulturna osvita : teoretychni zasady reformuvannia [Multicultural education: theoretical principles of reform]. Pedahohichnyi dyskurs. Khmelnytskyi : KhHPA, 28-36. [in Ukrainian].

17. Domina, V. (2017). Kontseptualni osnovy vykhovannia bilinhvalnoi kultury u maibutnikh uchyteliv inozemnykh mov [Conceptual bases of education of bilingual culture at future teachers of foreign languages.]. Teoriia ta metodyka navchannia ta vykhovannia, 43, 90-101. Retrieved from http://journals.hnpu.edu.ua/index.php/methodics/article/view/836 [in Ukrainian].

18. Kendzor, P. (2017). Polikulturne vykhovannia uchniv u systemi diialnosti zahalnoosvitnoho navchalnoho zakladu (teoriia i metodyka) [Multicultural education of students in the system of activity of a general educational institution (theory and methods)]. (Doctoral dissertation). Kyiv : Akademiia pedahohichnykh nauk Ukrainy. Instytut problem vykhovannia. [in Ukrainian].

19. Kondratieva, O. M. (2017). Formuvannia polikulturnoi kompetentnosti maibutnikh uchyteliv pochatkovoi shkoly (na zasadakh linhvokrainoznavchoho pidkhodu) [Formation of

Професіоналізм педагога: теоретичні й методичні аспекти. - Вип. 16. - Слов'янськ, 2021. 


\section{В. ОЛІШЕВИЧ}

Історико-теоретичні аспекти полікультурної компетентності майбутнього вчителя іноземної мови

multicultural competence of future primary school teachers (on the basis of linguistic approach)]. (PhD dissertation). Kyiv : Natsionalnyi pedahohichnyi universytet im. M. P. Drahomanova. [in Ukrainian].

20. Kostiuchenko, A. (2015). Analiz poniattia «mizhkulturna kompetentnist uchytelia» [Analysis of the concept of "intercultural competence of teachers"]. Pedahohichni nauky, 64, 29-33. Retrieved from http://dspace.pnpu.edu.ua/bitstream/123456789/5578/1/Kostyuchenko.pdf. [in Ukrainian].

21. Motsar, M. M. (2018). Formuvannia polikulturnoi kompetentnosti maibutnikh perekladachiv z vykorystanniam tekhnolohii dystantsiinoho navchannia [Formation of multicultural competence of future translators with the use of distance learning technologies]. (PhD dissertation). Kyiv : Natsionalnyi pedahohichnyi universytet im. M. P. Drahomanova. [in Ukrainian].

22. Olishevych, V. M. (2020). Formuvannia polikulturnoi kompetentnosti maibutnikh uchyteliv inozemnykh mov u protsesi profesiinoi pidhotovky [Formation of multicultural competence of future foreign language teachers in the process of professional training]. (PhD dissertation). Sloviansk: DVNZ «Donbaskyi derzhavnyi pedahohichnyi universytet». [in Ukrainian].

23. Peretiaha, L. Ye. (2008). Dydaktychni umovy formuvannia polikulturnoi kompetentnosti molodshykh shkoliariv [Didactic conditions for the formation of multicultural competence of junior schoolchildren]. (PhD dissertation). Kharkiv : Kharkivskyi natsionalnyi pedahohichnyi universytet imeni H.S. Skovorody. [in Ukrainian].

24. Law of Ukraine On Education (2017). Retrieved from https://zakon.rada.gov.ua/laws/show/2145-19\#Text. [in Ukrainian].

25. Rezunova, O. (2021). Mizhkulturna kompetentnist yak neobkhidna skladova profesiinoi kompetentnosti suchasnoho fakhivtsia [Intercultural competence as a necessary component of professional competence of a modern specialist]. Naukovyi ohliad, 1(73). Retrieved from http://oaji.net/articles/2021/797-1614450760.pdf. [in Ukrainian].

26. Sysoieva, S. \& Sokolova, I. (2016). Teoriia i praktyka vyshchoi osvity : navchalnyi posibnyk [Theory and practice of higher education: a textbook]. Kyiv-Mariupol : MDU. [in Ukrainian].

27. Cherednychenko, L. A. (2013). Etapy formuvannia polikulturnoi kompetentnosti maibutnoho vchytelia inozemnykh mov u protsesi profesiinoi pidhotovky. Problemy suchasnoi pedahohichnoi osvity [Stages of formation of multicultural competence of the future teacher of foreign languages in the process of professional training]. Pedahohika i psykholohiia, 39 (4), 333337. [in Ukrainian].

Матеріали надійшли до редакції 15.10.2021 р. 